\title{
The Kölner Fechtbuch: Context and Comparison
}

\author{
Keith Farrell \\ Academy of Historical Arts, keith@triquetra-services.org
}

\begin{abstract}
The Kölner Fechtbuch is a fascinating, unique treatise from the $16^{\text {th }}$ century. Although it is tempting to compare it with the Liechtenauer tradition and to use knowledge, ideas and concepts from that tradition to interpret this book, this article shows that such an approach would be flawed. To demonstrate a proper examination and analysis of the longsword fighting system within the Kölner Fechtbuch, this article compares and contrasts it with $15^{\text {th }}$ and $16^{\text {th }}$ century sources with a connection to the Liechtenauer tradition, along with $16^{\text {th }}$ century sources from other traditions. Furthermore, this article examines the Fechtschulen, their rules and their context, in an attempt to demonstrate that the Kölner Fechtbuch is an example of this style of fighting.
\end{abstract}

Keywords - Kölner Fechtbuch, Fechtschule, longsword, fencing

\section{INTRODUCTION TO THE KÖLNER FECHTBUCH}

The Kölner Fechtbuch contains an intriguing collection of fencing treatises from the $16^{\text {th }}$ century. It has received relatively little attention from the HEMA community, and so my intention is to compare its longsword material with other sources and traditions to analyse its similarities and differences. Furthermore, I intend to examine the context of fencing in the Holy Roman Empire at the time period in question, and use this knowledge to give proper context to further interpretations of the fencing material contained within the Fechtbuch.

\section{I.1. About the Manuscript}

The "Kölner Fechtbuch" is a common name for the book bearing the access code MS Best.7020 (W*)150, held in the Historisches Archiv der Stadt Köln, the Historical Archives of the City of Cologne in Germany. It formed part of the Bestand collection, and came from the personal library of Ferdinand Franz Wallraf, who left his library to the city of Cologne when he died in 1824. The "Best.7020" section of the access code is not the signature of the document; it refers to a group of more than 300 manuscripts that form part of the Bestand collection. The " $\left(\mathrm{W}^{*}\right) 150$ " section of the access code is the signature that identifies this particular manuscript as item number 150 from 
Wallraf's bequest. ${ }^{1}$ The title of the book is recorded as "Fechtregeln" or "Fencing Rules". ${ }^{2}$

The manuscript is small, measuring just $145 \mathrm{~mm}$ in height by $100 \mathrm{~mm}$ in width. It contains 23 sheets of paper, several of which were left blank. ${ }^{3}$ It was written in High German with a Ripuarian dialect, ${ }^{4}$ mainly in black ink, although sentences began with a letter in red ink, and important points were underlined in red ink. ${ }^{5}$ The book was bound using pages from a $13^{\text {th }}$ century Gospel book. ${ }^{6}$

Other than a metallurgical recipe on folio $1 \mathrm{v}$ and an abecedarium on folio $20 \mathrm{r}$, the book contained five short fencing treatises, dealing with the arts of longsword, wrestling, messer (and dagger), spear and staff. The book has been dated to "around 1500" by Günter Gattermann, ${ }^{7}$ and to "the $16^{\text {th }}$ century" by Matthias Bauer. ${ }^{8}$ Karl Menne notes that the handwriting is from the $15^{\text {th }}-16^{\text {th }}$ centuries, circa $1500 .{ }^{9}$

Unfortunately on the $3^{\text {rd }}$ of March 2009, part of the Archives in Cologne collapsed due to issues with construction work on an underground metro line beneath the building, burying and destroying significant numbers of historical documents. However, by June of that same year, around $85 \%$ of the documents from that wing had been recovered. Less than a quarter of the documents were torn apart by the disaster, and experts have been working to piece back together the affected items. ${ }^{10}$

The current state of the Kölner Fechtbuch is unknown, but as of November 2014, it has not yet been recovered to a useable condition, meaning that it may not have been

1 Dieter Bachmann, 'Cologne Fechtbuch (English translation)', Schwertfechten.ch, 2014, <http://schwertfechten.ch/pdf/cologne_fechtbuch_english.pdf >, accessed 9th December 2014, p. 2.

${ }^{2}$ Karl Menne, Deutsche und niederländische Handschriften. Mitteilungen aus dem Stadtarchiv von Köln: Die Handschriften des Archivs, No. 10, Dept. 1, Part 2 (Köln: Verlan von Paul Neubner, 1937), Nr. 111, pp. 195-196.

3 'Köln, Hist. Archiv der Stadt, Best. 7020 (W*) 150', Handschriftencensus, <http://www.handschriftencensus.de/13145>, accessed 9th December 2014.

${ }^{4}$ Menne, Deutsche und niederländische Handschriften, pp. 195-196.

5 Ibid.

${ }^{6}$ Ibid.

7 Günter Gattermann, Handschriftencensus Rheinland. Erfassung mittelalterlicher Handschriften im rheinischen Landesteil von Nordrhein-Westfalen mit einem Inventar (Düsseldorf: Wiesbaden, 1993), t. 2, Nr. 2488, p. 1319.

8 Matthias Johannes Bauer, Langes Schwert und Schweinespieß. Die anonyme Fechthandschrift aus den verschütteten Beständen des Historischen Archivs der Stadt Köln (Graz: ADEVA, 2009).

${ }^{9}$ Menne Deutsche und niederländische Handschriften, pp.195-196.

10 'Construction worker confesses in Cologne archive collapse case', The Local: Germany's News in English, 2010, <http://www.thelocal.de/20100209/25131>, accessed 9th December 2014. 
found, or perhaps has been found but not yet put back together. ${ }^{11}$ However, recovery operations appear to be going well in general: the November 2014 catalogue of useable recovered documents spanned 744 pages, up from 611 pages in the August 2014 catalogue. ${ }^{12}$

\section{I.2. Reproductions and Access}

In 1965, the manuscript was recorded on microfilm (Kö. S. II 469). ${ }^{13}$

In 2007, Andreas Meier and Marita Wiedner produced a transcription of the text, completing a project that they had been working on since $2004 .{ }^{14}$

In 2009, Matthias Johannes Bauer transcribed the text, and published this along with colour scans of the manuscript in his book Langes Schwert und Schweinespieß. Die anonyme Fechthandschrift aus den verscbütteten Beständen des Historischen Archivs der Stadt Köln. ${ }^{15}$ Luckily, these scans were created shortly before the collapse of the Archives. Also in 2009, the Gesellschaft Lichtenawers historical fencing club in Corona produced a transcription of the text. ${ }^{16}$

In 2010, Daniel Jaquet translated the text into French. ${ }^{17}$

In 2011, James Acutt ${ }^{18}$ transcribed the book and translated all of its treatises into English. ${ }^{19}$

11 'Historisches Archiv der Stadt Köln: Liste der im Original nutzbaren Archivalien (Stand November 2014)', Das digitale Historiche Archiv Köln, November 2014, <http://www.archive.nrw.de/kommunalarchive/kommunalarchive_i-l/k/Koeln/

BilderKartenLogosDateien/20141117_im_Original_nutzbar.pdf>, accessed 9th December 2014.

12 'Historisches Archiv der Stadt Köln: Liste der im Original nutzbaren Archivalien (Stand August 2014)', Das digitale Historiche Archiv Köln, 2014, <http://www.archive.nrw.de/kommunalarchive/kommunalarchive_i-

1/k/Koeln/BilderKartenLogosDateien/20140825_im_Original_nutzbar.pdf $>， \quad$ accessed $9^{\text {th }}$ December 2014.

13 'Handschriften (W*) (Best. 7020) 150. Fechtregeln', Das digitale Historische Archiv Köln, <http://historischesarchivkoeln.de/de/lesesaal/verzeichnungseinheit/173032/Best. $+7020+150+$ Fechtregeln>, accessed 9th December 2014.

14 Andreas Meier and Marita Wiedner, 'Transkription von HS Best.7020 (alt W*Nr.150)', Gesellschaft für pragmatische Schriftlichkeit, 2007, <http://www.pragmatischeschriftlichkeit.de/Best7020.html>, accessed 9th December 2014.

15 Bauer, Langes Schwert und Schweinespieß.

16 Meier and Widener, 'Transcription Best.7020 (W* 150)'.

17 Daniel Jaquet, 'Travaux de transcription/traduction de documents sources Kölner Fechtbuch', Association GAGS (Gebennensis Artium Gladiatorium Schola), 2010, <http://gagschola.bluemindmusic.com/files/recherche/dj.trad.hsbest7020.pdf>, accessed 9th December 2014. 
In early 2014, Dieter Bachmann translated the longsword treatise into English. ${ }^{20}$ Later in 2014, Christian Trosclair prepared an English translation of the longsword treatise that became available through the Wiktenauer. ${ }^{21}$

\section{METHODOLOGY}

Since my early investigations into the Kölner Fechtbuch in 2012 were somewhat informal, without this publication in mind, the main challenge for this publication was to draw together my thoughts and understandings of various different topics and turn it into a cohesive and sensible piece of work.

My interpretive work on the Kölner Fechtbuch used the ADVISE model developed by Bartłomiej Walczak. ${ }^{22}$ Each technique was first analysed in terms of mechanics and performance, and then techniques were divided thematically into groups in terms of similarity or dissimilarity to techniques or sequences from the Liechtenauer tradition. The verification stage required that I try to use the techniques and strategies in fighting, which in turn required application of the AHA Technique Validation model. ${ }^{23}$ Interpolation required analysis of the general principles, which raised the suggestion that I should begin to read about the Fechtschulen. The results of these phases combined together in the synthesis stage, along with my skills as a teacher and course developer, to design a curriculum of study for practitioners of this fencing system. The external input phase required further reading of the various $16^{\text {th }}$ century sources such as Mair, Meyer, and the anonymous Codex Guelf 83.4 August. $8^{\circ}$, to help me put the techniques of the Kölner Fechtbuch into their context with regards to the Liechtenauer tradition and other unique traditions.

By teaching my interpretation of the Kölner Fechtbuch at events throughout the UK and Europe, it has given me the opportunity to ensure that my ideas make sense, and to revise them if necessary when challenged upon my assumptions. Many steps forward in

18 James Acutt published some work under the pseudonym "James Wallhausen". In footnotes I will use his pseudonym for the documents and publications bearing that name; otherwise, I will use his real name to refer to the man and his work.

19 James Wallhausen, 'The Fight-Lore of the Long Sword from the Kölner Fechtbuch (MS Best.7020)', Paleoeskirmology Historical Combat Systems, 2012.

${ }^{20}$ Bachmann, 'Cologne Fechtbuch (English translation)'

21 'Fechtregeln (MS Best.7020 (W*)150)', Wiktenauer, <http://wiktenauer.com/wiki/ Fechtregeln_(MS_Best.7020_(W*)150)>, accessed 9th December 2014.

22 Bartłomiej Walczak, 'Bringing Lost Teachings Back to Life - a Proposed Method for Interpretation of Medieval and Renaissance Fencing Manuals', IDO MOVEMENT FOR CULTURE. Journal of Martial Arts Antbropology, 11/2 (2011), 47-54.

${ }^{23}$ Keith Farrell, 'Validating What We Do in Martial Arts', in Encased in Steel Anthology I, ed. by Keith Farrell (Glasgow: Fallen Rook Publishing, 2015), pp. 199-208. 
my understanding of the material have come from informal conversations at events, just as many developments have come from reading books and articles on related subjects.

For writing this article, the methodology has been one of comparison: to identify the salient points about the Kölner Fechtbuch and its fighting style, to compare these with the salient points from other fencing treatises in order to compare styles, and finally to compare against the context of the Fechtschule as described in books, articles, and other publications.

\section{LITERATURE REVIEW}

This section will examine some of the most important and most useful resources (including works published both traditionally and informally) that can inform a study of $16^{\text {th }}$ century fencing in the Holy Roman Empire. It is upon these resources that much of this article has been based.

\section{III.1. Important Textbooks and Journals}

One of the most important textbooks to read for an overview and introduction to historical European martial arts is of course Professor Sydney Anglo's book The Martial Arts of Renaissance Europe. While this is a goldmine for many interesting snippets of information, unfortunately it contains very few references to the Fechtschulen, dealing more with knightly tournaments than competitions for burghers, and does not mention the Kölner Fechtbuch at all. ${ }^{24}$

A relatively new book that is of immense value is The Martial Ethic in Early Modern Germany by Professor B. Ann Tlusty. This work covers the other end of the spectrum that Professor Anglo does not discuss in his book: the context of civic duty and the rights of civilians to carry and use weapons in everyday life. The use of the sword was not exclusive to the upper class, and this textbook provides vast quantities of information about the relationship of the sword to the working classes such as craftsmen, merchants and journeymen. ${ }^{25}$ This book is probably one of the most important resources available to students and interpreters of $16^{\text {th }}$ century German martial arts, and is therefore crucial to understanding the context of the Kölner Fechtbuch.

Another academic source of information is the peer-reviewed journal Acta Periodica Duellatorum. The first and second volumes (2013 and 2014 respectively) have included several articles about fencing guilds, the Fechtschulen, and context for fencing in the $16^{\text {th }}$ century. ${ }^{26}$

\footnotetext{
24 Sydney Anglo, The Martial Arts of Renaissance Europe (New Haven: Yale University Press, 2000).

25 Ann B. Tlusty, The Martial Ethic in Early Modern Germany: Civic Duty and the Right of Arms (Basingstoke: Palgrave Macmillan, 2011).

26 Acta Periodica Duellatorum 1 (2013) and 2 (2014).
} 
Matthias Bauer's book Langes Schwert und Schweinespieß. Die anonyme Fechthandschrift aus den verscbütteten Beständen des Historischen Archivs der Stadt Köln is the only example of an entire book devoted to the Kölner Fechtbuch. It is written in modern German, so unfortunately its contents may be inaccessible for people who do not possess the necessary language skills.

\section{III.2. Sources from the $16^{\text {th }}$ Century}

To be able to compare and contrast with other $16^{\text {th }}$ century sources, it is important to use skilful translations that convey the information from the treatises effectively. To that end, one of the most helpful resources is The Art of Combat by Jeffrey Forgeng, a translation of Joachim Meyer's book Gründtliche Beschreibung der Kunst des Fechtens from 1570. ${ }^{27}$ Another helpful resource is Kevin Maurer's translation of Meyer's manuscript from 1560 that is without name, ${ }^{28}$ although it is known formally as the MS A.4 ${ }^{\circ} .2$ at the University Library of Lund.

Examples of longsword fencing from the first quarter of the $16^{\text {th }}$ century include Andre Paurñfeyndt's Ergrundung Ritterlicher Kunst der Fechterey from 1516, the anonymous treatise in the Goliath Fechtbuch (MS Germ.Quart.2020) from 1510-1520, the copy of Ringeck's treatise in the Glasgow Fechtbuch (MS E.1939.65.341) from 1508, and the CGM 3711 by Jörg Wilhalm Hutter from 1523. Of these treatises, those by Ringeck, Wilhalm and the anonymous glossator exemplify more of a $15^{\text {th }}$ century method of fighting; only Paurñfeyndt's treatise is significantly different from the methods of the final quarter of the previous century. Therefore, we can surmise that in the first quarter of the $16^{\text {th }}$ century, longsword fencing was still similar to that of the previous century, although it was developing differences, along with new emphases and ideas.

An example of fencing from the second quarter of the $16^{\text {th }}$ century can be seen in Keith Myers' of Paulus Hector Mair's Opus Amplissimum de Arts Atbletica from c.1542. ${ }^{29}$ Mair did not gloss the Liechtenauer tradition in the same way as previous masters from the $15^{\text {th }}$ or early $16^{\text {th }}$ centuries, but rather attempted to compile as complete a record as he could of the various fencing techniques and disciplines used in his time. The method of longsword described in his Opus can therefore be regarded as fairly representative of longsword fencing in the $2^{\text {nd }}$ quarter of the $16^{\text {th }}$ century.

Meyer's books from 1560 and 1570 are very similar to each other in some respects, but are quite different in others. The 1560 treatise discusses more of the "ancient" methods

${ }^{27}$ Jeffrey Forgeng, The Art of Combat: A German Martial Arts Treatise of 1570 (New York: Palgrave MacMillan, 2006).

28 Joachim Meyer, c.1560. Lund, Lunds Universitets Bibliotek, MS A.4².2, translated by Kevin Maurer, 2012, <https://sites.google.com/site/jochimmeyer1560/>.

29 Paulus Hector Mair, c.1542. Dresden, Sächsische Landesbibliothek, MS Dresd.C.93, translated by Keith P. Myers, 2011. 
of fighting, while the 1570 treatise focuses more on Meyer's own methods. They provide an important example of fencing in the third quarter of the $16^{\text {th }}$ century.

Meyer's book from 1570 was reprinted in 1600, 1610 and 1660. In 1612, Jakob Sutor von Baden produced his New Kuinstliches Fechtbuch, which contained significant quantities of Meyer's teachings. Keith Myers has also translated this work. ${ }^{30}$ Sutor's adoption of Meyer's teachings, along with the reprints of Meyer's work, shows that Meyer's longsword method can be representative of longsword fencing from the $4^{\text {th }}$ quarter of the $16^{\text {th }}$ century and even into the $17^{\text {th }}$ century.

\section{III.3. Modern Blogs and Websites}

Roger Norling runs the website $H R O A R R,{ }^{31}$ that is updated on a weekly basis with a new article, essay or translations from scholars and writers within the HEMA community. Many of these articles are useful for the study of $16^{\text {th }}$ century fencing and its context in the Holy Roman Empire and in the Italian Kingdoms at that time.

Jens P. Kleinau runs a blog entitled Hans Talboffer as seen by Jens P. Kleinau, ${ }^{32}$ where he posts translations, transcriptions and other articles on a more irregular basis. Many of these transcriptions and translations deal with documents from city archives about fencing masters, guilds and Fechtschulen, making them of value to students of $16^{\text {th }}$ century fencing.

A final online resource that contains many useful articles and translations is the website of the Meyer Freifechter Guild, ${ }^{33}$ an international body of practitioners and researchers who study the works of Joachim Meyer. They also post resources that deal with other masters from the $16^{\text {th }}$ century and articles that discuss concepts found throughout the art of fencing from that century, with significant discussion of the Fechtschulen.

\footnotetext{
30 Jakob Sutor. New Kinstliches Fechtbuch. Frankfurt am Main: Wilhelm Hoffman, 1612. Translated by Keith P. Myers, 2010.

${ }^{31}$ HROARR, < http://www.hroarr.com/>, accessed 11 th December 2014.

32 Hans Talhoffer as seen by Jens P. Kleinau, <http://talhoffer.wordpress.com/>, accessed $11^{\text {th }}$ December 2014.

33 Meyer Freifechter Guild, <http://freifechter.com/>, accessed 11th December 2014.
} 


\section{INTERPRETATIVE WORK}

I have been working with the Kölner Fechtbuch in an interpretive fashion since late 2012, and have taught my understanding of the longsword material at several events throughout Europe. ${ }^{34}$ This section will discuss my findings in terms of the stylistic elements of the treatise. It is helpful to identify the pertinent stylistic elements of the system so that there are points for comparison with other fighting systems from the same century.

To develop my interpretation, I worked with the English translation produced by James Wallhausen in 2011. There were no other English translations available at the time and my own ability to translate $15^{\text {th }}$ and $16^{\text {th }}$ century dialects of German was not good enough to create my own translation of the rather difficult material found in this book. Therefore, I approached my interpretation aware of the fact that the difficulty and obscurity of the original language resulted in a translation that was not perfect (as is, of course, the case with many translations of many different works) but that did its best to represent the sense of the treatise ${ }^{35}$ and that as a result, many of my ideas might well be incorrect, as any translation work would need to involve a significant amount of interpretation, guesswork and decision-making on the part of the translator just to render it into English in the first place, before any physical interpretation could begin. ${ }^{36}$

With this in mind, I decided to make the most interesting interpretation I could. Even if it was not "right", it could still be interesting, and could still teach valuable fencing skills that are found less often in other treatises. Since it is clear from the longsword text that there were no thrusts (other than a single feint) and no instructions to strike at the hands, I decided it was reasonable to interpret the system as a fighting style for the Fechtschule. Therefore, from the beginning, I chose to interpret everything as "sport fencing" in the fashion of the Fechtschule, rather than trying to make it into an "ernstfechten" system with lethal techniques for judicial duels.

Thus I made some basic assumptions to start with, and worked from there to interpret the longsword material. Throughout the process, I bore in mind that my basic assumptions may have been flawed, and that the choice of phrases in the translation may have coloured my interpretation. I could not assert that my interpretation was $100 \%$ correct or even

\footnotetext{
34 Keith Farrell,'The Kölner Fechtbuch', video clip of a workshop at the Dreynevent 2014, hosted on Youtube, 2014, <https://www.youtube.com/watch?v $=\mathrm{aBxHNnuzvvU>}$, accessed $11^{\text {th }}$ December 2014.

35 I must emphasise that I feel greatly indebted to James Acutt for the efforts he made with his translation of the Kölner Fechtbuch. It was clearly a difficult translation to make, and I could not hope to achieve anywhere near the same quality of work that he managed if I had attempted to make a translation myself.

${ }^{36}$ Keith Farrell, 'Research into Historical European Martial Arts', Encased in Steel Anthology I., ed. by Keith Farrell (Glasgow: Fallen Rook Publishing, 2015), pp. 65-85.
} 
$100 \%$ supported by the text; but nonetheless, from the exercise, I could learn some interesting and valuable lessons about fencing, and pass these lessons to my students.

\section{IV.1. Key Stylistic Elements}

Since I have only worked in-depth with the longsword treatise, the following stylistic elements all relate to fencing with the longsword, with only minor reference to another treatise in the book.

The technical terms drawn from the Kölner Fechtbuch are spelled as per Bauer's transcription. Consistency of spelling of technical terms representative of the Liechtenauer tradition from other sources is difficult, due to the wide variety of spellings employed by different authors; my methodology for ensuring consistency within this article is to spell technical terms in the fashion set out in the AHA German Longsword Study Guide, based on the representative gloss of Ringeck from the $M S$ Dresd.C.487.37 Quotes from the Kölner Fechtbuch are drawn from Bauer's edition; quotes of transcriptions from other sources do not follow any single norm of transcription, as the transcribers did not meet scientific edition criteria and self-published electronically. It is out of the scope of my project to correct these quotes, and I am not discussing linguistic issues when comparing technical terms.

I believe that fighting in the style of the Kölner Fechtbuch works best when conducted with a federschwert, rather than a more conventional sword. The style requires a lot of striking from side to side, which works better with a lighter blade and with a longer grip. ${ }^{38}$ Furthermore, virtually all the swords depicted in the $16^{\text {th }}$ century books by Medel, Mair, Meyer, and Sutor are of the "federschwert" type, usually with narrower blades and a flared "schilt" at the base of the blade. Roger Norling has written extensively on HROARR about the federschwert, ${ }^{39,40}$ and it is from his research and the consistent illustrations in other $16^{\text {th }}$ century books that led to the conclusion that the federschwert is the appropriate tool for this style of fighting.

The longsword treatise deals primarily with cutting/striking techniques and with grapples. There is only a single thrust described in the treatise, and that appears to be

37 Keith Farrell and Alex Bourdas, AHA German Longsword Study Guide (Glasgow: Fallen Rook Publishing, 2013), pp. 10-11 and 113-116.

38 Keith Farrell, 'Comparing how swords were used - the importance of the hilt', Encased in Steel, 2012, <www.encasedinsteel.co.uk/2012/12/28/comparing-how-swords-were-used-theimportance-of-the-hilt/>, accessed 11th December 2014.

39 Roger Norling, 'The WhatChaMaCallit-Schwert', HROARR, 2013, <http://www.hroarr.com/the-feder-whatchamacallit/>, accessed 11th December 2014.

40 Roger Norling, 'Fechtschwert or a blunt longsword?', HROARR, 2011, <http://www.hroarr.com/federschwert-or-a-blunt-longsword/>, accessed 11th December 2014. 
more of a provoking/feinting action at the beginning of the play named der ocks. ${ }^{41}$ There are no directions to strike at the hands; but nor are they any directions not to strike at the hands. However, the hands are targeted explicitly in earlier treatises, for example when describing the Krumphaw, ${ }^{42,43,44}$ or when describing certain halfswording techniques, ${ }^{45,46}$ so the fact that the Kölner Fechtbuch does not call for such targeting explicitly is a good reason to suggest that the hands were not an important target within this fighting system. Therefore, stylistically, this system seems to place emphasis upon cutting and grappling techniques, with limited target areas.

However, the messer treatise does include the concept of thrusts. It includes a feinting thrust in the technique called dem ocksen stoe $\beta,{ }^{47}$ another technique called den langen stych, ${ }^{48}$ and also a technique called den zorn stych. ${ }^{49}$ Clearly the author of the treatise was familiar with the concept of thrusting, both offensively and defensively. Since the messer treatise bears many similarities to the longsword treatise, it is safe to assume that the same individual authored both treatises. Therefore, the author of the longsword treatise was probably familiar with thrusting techniques, both offensively and defensively, but chose not to write about them for the longsword. This suggests that the author may have viewed the messer as a more serious weapon for self-defence, while the longsword may have been less important for this purpose.

There do not appear to be any winding actions in the Kölner Fechtbuch, at least not in the same fashion as per treatises that describe the Liechtenauer tradition. There is no mention of anything like a Zornhaw Ort, nor Mutieren. There is a concept called doppeleren in the messer treatise, ${ }^{50}$ that could potentially be understood as Duplieren in the Liechtenauer sense of a winding action in the bind, or it could be understood more in the sense of Joachim Meyer's where an attack to an opening is "doubled" by performing a second cut to the same opening, often with the other edge. ${ }^{1}$ Nonetheless, there is

41 Anonymous, c.1500s. Cologne, Historisches Archiv der Stadt Köln, MS Best.7020 (W*)150, fol. 5r. Hereafter referred to as MS Best.7020.

42 Sigmund Ringeck, c.1504-19. Dresden, Sächsische Landesbibliothek, MS Dresd.C.487, fols. 24v-27r. Hereafter referred to as MS Dresd.C.487.

43 Peter Falkner, c.1495. Vienna, Kunsthistorisches Museum, MS KK5012, fol. 4v.

44 Anonymous, 1452. Rome, Accademia Nazionale dei Lincei, Codex 44.A.8, fol. 16v-18v.

45 Hans Talhoffer, 1467. Munich, Bayerische Staatsbibliothek, Codex icon.394a, fol. 23v.

46 Anonymous, c.1430s. Vienna, Kunsthistorisches Museum, MS KK5013, fol. 7v.

47 MS Best.7020 (W*)150, fol. 15r.

48 Ibid., fol. $14 \mathrm{v}$.

49 Ibid.

50 Ibid., fol. 16 r.

51 Joachim Meyer, Gründtliche Beschreibung der Kunst des Fechtens(Strasbourg: Thiebolt Berger, 1570), pp. $10 \mathrm{r} .1 .19 \mathrm{r}-1.19 \mathrm{v}$. 
certainly not the same emphasis on working within the bind as can be found in the various treatises glossing the Liechtenauer tradition.

As a result, many (if not most) techniques in the Kölner Fechtbuch involve striking from side to side. There is not the same emphasis placed upon remaining in control of the centre-line as can be inferred from the Liechtenauer method of winding; to wind successfully, one must first control the centre-line and then further attempt to shut down the opponent's opportunities to use his sword in the bind. ${ }^{52}$ Ideally, the best kind of action from the bind is something straight along the centre-line, such as the Zornhaw Ort, where the Zornhaw gains control of the centre-line and the Ort is merely a straight thrust (with opposition) without any further vertical or horizontal winding motions. Alternatively, if the opponent is stronger or better positioned in the bind, and has taken control of the centre-line, the Liechtenauer tradition includes methods of winding around his blade with techniques like Duplieren or the Eußern Nym. Control of the centre-line is clearly very important in Liechtenauer's system. ${ }^{53}$

Without using winding actions, control of the centre line is less important in the Kölner Fechtbuch. Obviously, one's cutting mechanics should attempt to secure the centre-line, because ignoring it would be a very poor idea, but if the opponent parries a cut then there is not the same need to establish control of the centre-line in order to wind; the preferred response to such a situation in the Kölner Fechtbuch is to take off and strike round to the other side. When accompanied by an appropriate step, this action establishes a new centre-line. Therefore, a fighter is creating new centre-lines and always modifying his choice of angle of approach, rather than attempting to control a given centre-line as per the Liechtenauer method. Striking from side to side with appropriate steps is therefore a key part of this fighting system.

Leading on from this stylistic element, another focus of this system is creating sensible, functional sequences of strikes, rather than trying to land single direct attacks in a "sniping" fashion. Most, if not all, of the Fechtbücher that I have examined and interpreted seem to display this same idea. Single "sniping" attacks tend not to be the focus of any in-depth treatise on fencing, although they should not necessarily be ignored: Liechtenauer wrote in his Zettel "do not refrain from swift strikes". 54 However, in the Kölner Fechtbuch, the sensible and functional sequencing of attacks to overwhelm a defence from different sides and angles is a key stylistic element.

An interesting item that I have taken from the description of dy vyer an bynde (the four bindings) is that there is a concept of the "ideal bind" to facilitate the next strike. You bind with the short edge towards the upper and lower left openings (on the right side, as

\footnotetext{
52 Keith Farrell, 'The Pedagogical Skill of Andre Lignitzer, a 15th Century Fencing Master', Katsujinken: A Sword Arts Journal, 5(2013), pp. 12-15.

53 Farrell and Bourdas, AHA German Longsword, pp. 69-75.

54 MS Dresd.C.487, fol. 13r. Translated by Keith Farrell, 2013.
} 
you see them), with the long edge to the upper right opening (left as you see it), and with the flat to the lower right opening (left as you see it). ${ }^{55}$ These positions provide bounce and spring to help accelerate the following striking-round action, and they place the hand and wrist in the appropriate place to make the next action in a single rotational movement, rather than having to manipulate the wrist, fingers and thumb midmovement.

Liechtenauer's tradition places emphasis upon having a strong structure in the bind in order to facilitate the forthcoming winding action. For this reason, the Zettel and its glossators stress that a right-handed fencer should only make his initial strike from the right shoulder, not from the left, ${ }^{56}$ since this will result in the best possible structure in the bind, giving the fencer security while setting him up for a greater chance of success when winding from that position. However, since winding is not a stylistic element of longsword fencing in the style of the Kölner Fechtbuch, creating this kind of structure in the bind is not helpful. Instead, since leaving the bind and striking round to the other side is one of the main stylistic elements, one's structure in the bind should facilitate this kind of motion. Binding with the short edge from the right side allows for swift long edge strikes around to the left; binding with the long edge to the upper opening from the left allows for a swift short edge strike such as a Zwerbaw back around to the right, while binding with flat to the lower opening on the left allows for a very swift bounce back around with the short edge to the head. This is very useful in sequences such as der flogel, which is a perfect example of how to utilise these ideal positions in the bind to set up the following striking action..$^{57}$

Another interesting stylistic element is that sometimes the fencer should refuse blade contact, to limit tactile feedback for the opponent, and to create openings. Two techniques exemplify this perfectly: das verzocking is is virtually der flogep9 without the blade contact, and der schilder 60 is virtually der durch weschell61 without blade contact. Combined with items such as the provoking thrust at the beginning of der ocks, it seems that feinting (with and without blade contact) is a major stylistic element of this system.

The final stylistic element is that parries should always have the hands low and the point upward. There does not seem to be any "hanging guard" in the longsword section, nor any instruction to receive strikes in the "schilt" position (what is commonly known as the Ochs guard). There are only two defensive techniques in the treatise: der pluck and der

\footnotetext{
55 MS Best.7020 (W*)150, fol. 3v.

56 MS Dresd.C.487, fols. $14 \mathrm{r}-14 \mathrm{v}$.

${ }_{57}$ MS Best.7020 (W*)150, fol. 3v.

58 Ibid., fols. $3 \mathrm{v}-4 \mathrm{r}$.

${ }^{59}$ Ibid., fol. $3 \mathrm{v}$.

60 Ibid., fol. $4 \mathrm{v}$.

61 Ibid., fol. 4r.
} 
olber. In der pluck, the fencer turns from one lower position to the other, keeping his point high, and defends himself by placing the strong of his blade correctly in the path of the incoming strike. ${ }^{62}$ In der olber, the fencer performs what is commonly known as a Zwerbaw, but from the lower position; in other words, the point remains high, giving cover to the head, until it is time to sling the blade into the counter-cut by turning the thumb underneath. ${ }^{63}$

Comparatively, in the messer treatise, there is mention of dem bogell64 (the bow, a familiar messer and dussack technique used by Meyer and Lecküchner) and the bangenden ort ${ }^{65}$ (hanging point, a term used by Mair and Meyer). Again, this shows that the author was aware of these types of techniques, and found them valuable enough in certain situations to include them in one of his treatises, but perhaps did not find them entirely appropriate for longsword fencing, for whatever reason.

With only two named defensive techniques, and several named sequences for taking the attack to the opponent, it seems that the style of the Kölner Fecbtbuch is more offensive than defensive in nature, with an implicit requirement to take the $V o r$ and be active in maintaining initiative and pressure upon the opponent.

\section{SIMILARITY TO THE LIECHTENAUER TRADITION}

From the previous section discussing the main stylistic elements of the Kölner Fecbtbuch, it is already clear that there are some similarities and differences between this source and the Liechtenauer tradition of longsword fencing. This section will now examine the similarities and dissimilarities, so that the relationship of this book to the tradition can be seen more clearly.

\section{V.1. The Zettel}

The Liechtenauer tradition is based on the Zettel attributed to Johannes Liechtenauer, explained and expanded upon later by glossators and other fencing masters and enthusiasts. Therefore, the Zettel is the natural starting place for these comparisons.

There is no one single definitive version of the Zettel. Instead, we have different stemma of the Zettel; speaking in terms of a philological tradition, there are several witnesses to the stemma codicum, showing different branches and lines of development of the Zettel. James Acutt has some work in progress, analysing the various stemma of the Zettel, but unfortunately it has not yet been published. ${ }^{66}$ From a brief excerpt that he was kind

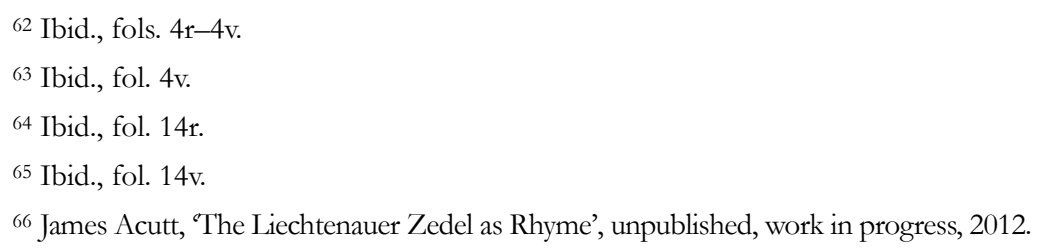


enough to send me in 2012, his findings at the time suggested that the copy of the Zettel in the $H s .3227 a$ is most likely the closest version to the original Zettel, so it is this version that I will use for the comparison.

The longsword treatise in the Kölner Fechtbuch begins with the line:

Hyr hebet sich aen der text und zedell ym langen sweerd. ${ }^{67}$

Here begins the text and schedule [Zedell] of the longsword. ${ }^{68}$

Normally in this subject area, the word "Zettel' (or any spelling thereof) refers to Liechtenauer's poem, but the Kölner Fechtbuch makes no such claim. It appears to be claiming to be its own authority on the subject, rather than deriving authority from the lineage of Liechtenauer. For the rest of this section, to improve the flow of the prose, the word 'Zettel' will refer to Liechtenauer's Zettel, to avoid having to use Liechtenauer's name repeatedly as a qualifier.

The description of der olber in the Kölner Fechtbuch is very similar to the description of the Zwerhaw (written as Twerehawe in the Hs.3227a) found in the Zettel. The text in the Zettel says:

Twere benym $\sim$ et $\bullet /$

was von dem tage dar kïm $\sim$ et 69

The Cross Strike takes away

That which comes from the roof. ${ }^{70}$

Comparatively, the Kölner Fechtbuch says of der olber that:

was der man slecht van dach das kan man dar myt brechenn. ${ }^{71}$

What one strikes from the roof, with [this] one can break it. ${ }^{72}$

The gist of this statement is very similar between the two sources. This is not to say that the author of the Kölner Fechtbuch copied the text straight from the Liechtenauer tradition, but it does show that there is similarity in the description of the technique. At some point, the author may well have come into contact with a school of thought very similar to that of the Liechtenauer tradition with regards to this technique.

${ }^{67}$ MS Best.7020 (W*)150, fol. 2r. Transcribed by Matthias Johannes Bauer, 2009.

68 Ibid. Translated by Keith Farrell, 2014.

69 Anonymous, c.1389. Nuremberg, Germanisches Nationalmuseum, MS 3227a, fol. 27r. Transcribed by Dierk Hagedorn, 2008. Hereafter referred to as MS 3227a.

70 Ibid. Translated by Keith Farrell, 2014.

71 MS Best.7020 (W*)150, fol. 4v. Transcribed by Matthias Johannes Bauer, 2009.

72 Ibid. Translated by Keith Farrell, 2014. 
Another similarity is a note about strong and weak, length and mass. The text in the Zettel says:

\section{alle ding haben vale moße $e^{73}$}

All things have length and mass. ${ }^{74}$

Similarly, the Kölner Fechtbuch notes that:

alle konst halt lengen may $\beta^{75}$

All art has length and mass. ${ }^{76}$

Another similarity is in the warning from the Zettel that one should not learn to fence if he frightens easily:

Irschrikstu gerne /

key $\sim$ fechte $\sim$ nym $\sim$ er lerne 77

If you are easily frightened,

You will never learn fencing. ${ }^{78}$

The Kölner Fechtbuch makes a very similar point:

erschrecks du gerne /

keyn fecbten nummer enlern. ${ }^{79}$

If you are easily frightened,

You will never learn fencing. ${ }^{80}$

The statement is written in such a similar fashion that the translation may as well remain the same.

There are other small statements and phrases throughout the longsword treatise in the Kölner Fechtbuch that are very reminiscent of lines and phrases in Liechtenauer's Zettel. The Kölner Fechtbuch is clearly not an attempt to gloss Liechtenauer's Zettel, as it does not follow the same structure, nor does it address many of items, techniques and concepts within the Zettel. However, there are some similarities, enough to be more than mere coincidence. The most likely explanation is that some of the couplets and phrases from the Zettel had become common enough phrases in the art of swordsmanship by the time the Kölner Fechtbuch was written that the author was able to absorb them into his writing without trying to quote Liechtenauer directly.

\footnotetext{
73 MS 3227a, fol. 18r. Transcribed by Dierk Hagedorn, 2008.

74 Ibid. Translated by Keith Farrell, 2014.

75 MS Best.7020 (W*)150, fol. 8r. Transcribed by Matthias Johannes Bauer, 2009.

76 Ibid. Translated by Keith Farrell, 2014.

77 MS 3227a, fol. 18v. Transcribed by Dierk Hagedorn, 2008.

78 Ibid. Translated by Keith Farrell, 2014.

79 MS Best.7020 (W*)150, fol. 6v. Transcribed by Matthias Johannes Bauer, 2009.

80 Ibid. Translated by Keith Farrell, 2014.
} 


\section{V.2. $1^{\text {th }}$ Century Sources}

Now to compare the Kölner Fechtbuch with $15^{\text {th }}$ century glosses of Liechtenauer's fighting system.

The most important $15^{\text {th }}$ century glosses are those copies of the anonymous gloss in the Codex 44.A.8 (aka the Codex Danig), the Codex I.6.4 .3 (aka the Codex Lew), and the MS M.I.29 (aka the Codex Speyer). This anonymous gloss is very similar in content to the gloss by Sigmund Ringeck, recorded in the MS Dresden C487 (aka the Codex Ringeck) and the MS E.1939.65.341 (aka the Glasgow Fechtbuch). Although these two manuscripts date to the early $16^{\text {th }}$ century, I will include the gloss as a $15^{\text {th }}$ century source, since it clearly describes a $15^{\text {th }}$ century method of fighting. Similarly, the copy of the anonymous gloss in the MS Germ.Quart.2020 (aka the Goliath Fecthbuch) is found in a $16^{\text {th }}$ century manuscript, but is a copy of a $15^{\text {th }}$ century gloss.

The works by Paulus Kal, Hans Talhoffer and Peter Falkner (amongst others) are not as important for the purpose of this comparison. Although Kal's work is important in terms of being the first illustrated version of the Zettel, there is no gloss to describe the images further. Likewise, Talhoffer's and Falkner's work do not include a gloss of Liechtenauer's verses. Other $15^{\text {th }}$ century sources such as the Codex I.6.4 .2 (aka the Codex Wallerstein) and the Gladiatoria group of manuscripts do not attempt to gloss Liechtenauer's Zettel, and therefore are not quite as useful for this comparison. Nonetheless, these other sources are helpful, as they do describe some techniques not mentioned by the more comprehensive glosses.

The Kölner Fechtbuch uses many names that are similar to those found in the Liechtenauer tradition, but often for other techniques. For example, in the $15^{\text {th }}$ century glosses, Alber is the name of our of the four positions, with the sword pointed at the ground in front of the fencer; 81,82 in the Kölner Fechtbuch, der olber is the name for a strike reminiscent of the technique named the Zwerhaw in the glosses. ${ }^{83}$ Two more examples are der ocks and dy yser porte, both of which are strikes in the Kölner Fechtbuch, ${ }^{84}$ but guard positions in the glosses; ${ }^{85,86}$ although the yser porte (Iron Gate) is not common in these glosses, it is found throughout other $15^{\text {th }}$ century texts that are linked to the Liechtenauer tradition. ${ }^{87,88,89}$

81 MS Dresd.C.487, fol. 34v.

82 Roma, Accademia Nazionale dei Lincei et Corziana, Codex 44.A.8, fol. 26r. Hereafter referred to as Codex 44.A.8.

83 MS Best. $7020\left(\mathrm{~W}^{*}\right) 150$, fol. $4 \mathrm{v}$.

${ }^{84}$ Ibid., fols. 4 r, 5 r.

85 MS Dresd.C.487, fol. 34r.

${ }^{86}$ Codex 44.A.8, fol. $25 \mathrm{v}$.

87 Sigmund Ringeck, 1508. Glasgow, Glasgow Museums, MS E.1939.65.341, fol. 22v.

88 Codex icon.394a, fol. 9v. 
There is a technique called Durchwechseln in the glosses, which is a disengagement from one side of the opponent's blade to the other, usually to threaten a thrust. ${ }^{90,91}$ In the Kölner Fechtbuch, there is a technique called der durch weschell that has a similar idea but a different implementation: after binding on one side, the fencer frees his blade and strikes round to the other side..$^{22}$ It is a form of disengaging and posing threat on the other side of the opponent's blade, but the implementation is very different.

In the flourish at the beginning of the Kölner Fechtbuch, there is mention of the "weschel" which appears to be a guard position leading into a rising short edge cut, ${ }^{93}$ similar to the position of Wechsel or Wechselbut, which often lead into rising short edge cut called the Wechselhaw. ${ }^{94}$ The position and the cut are found in both $15^{\text {th }}$ and $16^{\text {th }}$ sources connected with the Liechtenauer tradition, although they are not mentioned in the anonymous gloss or in the Ringeck gloss.

Another similarity is the technique called der sprech vinster in the Kölner Fecbtbuch, which is described as a winding action, with crossed arms, that allows a fencer to read the opponent's intention and respond accordingly. ${ }^{95}$ This is similar to the Sprechfenster from the $15^{\text {th }}$ century glosses, where the intention is to allow a bind to occur, and to use the sense of Füblen to read the opponent's intention in order to make the appropriate response. ${ }^{96,97}$ While the $15^{\text {th }}$ century glosses tend to advise winding actions to follow the Sprechfenster, the Kölner Fechtbuch suggests that the fencer may strike at either side of his opponent once he divines his opponent's intent. Nonetheless, this technique is one of the strongest similarities between the Kölner Fecbtbuch and the $15^{\text {th }}$ century glosses.

\section{V.3. $16^{\text {th }}$ Century Sources}

In terms of the $16^{\text {th }}$ century sources in the Liechtenauer tradition, those of most importance are those by Paurñfeyndt, Mair and Meyer. Others of interest include the treatises by Jörg Wilhalm Hutter and Hans Medel.

The technique bearing the name der flogel is a typical $16^{\text {th }}$ century technique, written about by several masters, although described quite differently by each of them. The flogel (sometimes written as Flugel or Flugelhaw) is often a sequence, rather than a single

89 Hanko Döbringer, Andres Juden, Josts von der Nyssen, and Niclas Prewßen, c.1389. Nuremberg, Germanisches Nationalmuseum, MS 3227a, fol. 44v.

${ }^{90}$ MS Dresd.C.487, fol. $41 \mathrm{r}$.

91 Codex 44.A.8, fols. 30v-31v.

92 MS Best. $7020\left(\mathrm{~W}^{*}\right) 150$, fol. 4r.

93 Ibid., fols. 2r-2v.

${ }^{94}$ Farrell and Bourdas, AHA German Longsword, p. 48.

95 MS Best. 7020 (W*)150, fols. 5r-5v.

96 MS Dresd.C.487, fols. 47r-47v.

97 Codex 44.A.8, fols. 36r-36v. 
technique; but each version includes rising strikes, and virtually all of them include a rising long edge strike from the left with crossed wrists. This would seem to be the element within the sequence that links each version. The version of the sequence in the Kölner Fecbtbuch is most similar to the version described by Paurñfeyndt, which begins with an Oberbaw from the right, then an Underbaw from the left, and finish with an Oberhaw from the right. ${ }^{98}$ The version in the Kölner Fechtbuch is the same sequence, but it defines which edge to use for each strike. ${ }^{99}$

As discussed previously, der durch weschell in the Kölner Fechtbuch is similar in principle but different in implementation to the concept of Durchwechseln in the $15^{\text {th }}$ century glosses; it is also very similar to Joachim Meyer's concept of Ablauffen. ${ }^{100}$ Both der durch weschell and Meyer's Ablauffen exemplify the concept of yielding under the pressure of the opponent's blade, riding the momentum of his parry coupled with a moulinet-like action, and striking swiftly round to the other side; an action that is typically $16^{\text {th }}$ century in style, compared with the $15^{\text {th }}$ century stylistic element of remaining in the bind to work with winding actions and with the point.

A difference between the Kölner Fecbtbuch and the work by Mair and Meyer is in the frequency with which der olber ${ }^{101}$ is mentioned in the text, and the frequency with which it should be used in the conduct of a fight. In the Kölner Fechtbuch, der olber is mentioned only once, although in my interpretation of the material, the action of making a short edge, more-or-less horizontal strike into the "schilt" position (more commonly known as a left Ochs to Liechtenauer practitioners) is effectively the same strike: der olber seems to be a combination of a point-up defence with the sword, followed by slinging the blade round with the thumb underneath, and other techniques such as dy yser porte involve the same motion of striking with the short edge into the "schilt" position as part of a sequence of strikes. However, it seems to be a very marginal strike, not very common, and definitely not emphasised as something of particular importance.

Comparatively, Meyer says that:

The Thwart is one of the chief master techniques with the sword. For you should know, if the Thwart did not exist, then it would be like "half fencing", especially when you are under the opponent's sword and therein you can no longer attack with long cuts through the Cross. ${ }^{102}$

\footnotetext{
98 Andre Paurñfeyndt, 1516. Glasgow, Glasgow Museums, Ergrundung Ritterlicher Kunst der Fechterey, E.1939.65.357, p. A3r.

${ }^{99}$ MS Best.7020 (W*)150, fol 3v.

100 Meyer. Pages 1.18r-1.18v.

101 Called "die Zwirch" by Mair, and “der Zwerch” by Meyer.

102 MS A.4 $4^{\circ}$.2, fol. 25v. Translated by Kevin Maurer, 2012.
} 
Clearly the Zwerch was of great importance in Meyer's opinion. Likewise, the Zwirch was an important technique in the longsword treatise by Paulus Mair. From my own interpretive work on Mair's longsword, I believe that his style involves a simple decision-making process: if plan A fails (whatever plan A might be); then if the opponent is giving threat, make a Krump across his blade; but if he is not giving threat after foiling your plan A, then strike round with a Zwirch. ${ }^{103}$ Since this idea seems to be present in a high percentage of Mair's plays, the Zwirch is again clearly an important element within his system. The Kölner Fechtbuch is therefore significantly different from the systems of Mair and Meyer in this respect, since der olber is not an important technique and is not used very often in the longsword treatise.

An interesting similarity between the Kölner Fechtbuch and some of the other $16^{\text {th }}$ century sources is the feinted thrust at the beginning of der ocks. It requires a position that looks very similar to die Rosen according to Meyer, ${ }^{104}$ with the left hand inverted on the pommel of the sword. Mair also uses der Rosen in his longsword treatise, which appears to be more or less the same technique with the same implementation as in Meyer's work. ${ }^{105}$ However, the position of the hands is the main similarity between die Rosen and the initial thrust in der ocks, because the thrust then flows into a set of other strikes after (presumably) yielding to a parry of some description, whereas die Rosen would be more proactive in clearing the opponent's sword out of the way to set up the next strike. So the position of the sword with inverted left hand is a similarity, but the implementation of the technique differs quite significantly.

However, the feinted thrust in der ocks is a perfect example of Meyer's concept of "Provoker, Taker, Hitter". The Provoker is a technique that provokes the opponent into doing something; the Taker is a technique that takes the opponent's blade away so that it poses no threat; and the Hitter is a technique that hits the opponent. According to Meyer, these three types of strikes should be used in sequence together to create and hit an opening with the greatest possible safety and security. ${ }^{106}$ In the Kölner Fechtbuch, der ocks begins with a thrust towards the opponent's face, that then becomes a flogel and then another cut into the "schilt" position. ${ }^{107}$ This is a perfect implementation of a provoking action, a hitting action, then a taking action. Although the sequence of der ocks continues with further strikes, it could terminate safely at this stage during a fight after provoking an opening, hitting into that opening, then striking at the opponent's blade to bind him and prevent him from making some kind of Nachschlag or afterblow.

103 Keith Farrell, 'Paulus Hector Mair Longsword', video clip of a workshop at the Dreynevent 2014, hosted on Youtube, 2014, <https://www.youtube.com/watch?v=h4tnyaABUq8>, accessed 13 $3^{\text {th }}$ December 2014.

104 Meyer. Page $1.40 \mathrm{v}$.

105 MS Dresd.C.93, fol. 45r.

106 Meyer. Page 2.18r.

107 MS Best.7020 (W*)150, fol. 5r. 
A concept that both Paurñfeyndt and Meyer describe is the act of "slinging" (Schlaudern) with the flat of the blade upward to the ear. This is one of the small number of Underhaw-type strikes to bear a name; ${ }^{108}$ although Paurñfeyndt describes it as a sequence that concludes with a slinging strike with the flat of the blade, ${ }^{109}$ Meyer's description concentrates on the launching mechanic for a rising strike, without specifying the flat. ${ }^{110}$ This is similar to the fourth an bynde in the Kölner Fechtbuch, where one binds with the flat towards the lower right opening (lower left as you see it). ${ }^{111}$ In fact, the instruction in the Kölner Fechtbuch is to:

slage ym nach der rechten vnder bloyß myt der flech. ${ }^{112}$

strike in to the right lower opening with the flat. ${ }^{113}$

Rather than just binding with the flat, the instruction is to strike with the flat. This makes it similar in nature to the Schlaudern by Paurñfeyndt and Meyer, although this one is aimed at the lower opening, rather than at the head.

One final similarity worth discussing is the between the initial few strikes of the Kölner Fechtbuch and the teaching methods of the Marxbrïder, as described in the poem Fechtspruch written by Hans Sachs in 1548. In the introduction to his translation of the Kölner Fechtbuch, James Acutt makes some insightful comments about a potential relationship between this fighting style and the methods of the Marxbrüder. ${ }^{114}$

Sachs writes that the first techniques that a Marxbrüder would learn should be the Oberbaw, Underhaw, Mittelhaw and Flügelhaw. ${ }^{115}$ In the flourish at the beginning of the Kölner Fechtbuch, the concepts of the Oberhaw and Mittelhaw are definitely introduced; the concept of the Underhaw is introduced, although the technique is not named as such; and der flogel is the first technique that is named and described after the flourish and after the sections discussing the veyr leger and the vyer an bynde. ${ }^{116}$ This may be coincidental, or it may show some kind of link, or at least a common process of teaching.

Stylistically speaking, the Kölner Fecbtbuch bears more resemblance to the $16^{\text {th }}$ century sources from the Liechtenauer tradition than to the tradition's glosses from the $15^{\text {th }}$

108 Keith Farrell, 'Why do certain techniques have a name, when others do not?', Encased in Steel, 2013, <www.encasedinsteel.co.uk/2013/05/17/why-do-certain-longsword-techniques-have-aname-when-others-do-not/>, accessed 13 ${ }^{\text {th }}$ December 2014.

${ }^{109}$ E.1939.65.357, p. B.

110 Meyer, Grundtliche Beschreibung, p. 1.19r.

111 MS Best.7020 (W*)150, fol. 3v.

112 Ibid. Transcribed by Matthias Johannes Bauer, 2009.

113 Ibid. Translated by Keith Farrell, 2014.

114 Wallhausen.'The Fight-Lore', p. 4.

115 Ibid.

116 MS Best.7020 (W*)150, fols. 3r-3v. 
century. There are remarkable similarities between the system described in the Kölner Fechtbuch and the writings of Paurñfeyndt, and this would probably be the best source to study alongside the Kölner Fechtbuch for complementary material. There are also several similarities with Meyer's system, although there are also many differences evident between the Kölner Fechtbuch and Meyer's more advanced, more comprehensive system, enough to suggest that they were two quite separate systems with only cosmetic similarities. Although the Kölner Fechtbuch has been dated to "c.1500" or "16" century", my current personal assessment of its material and stylistic components is that it is most like the style of fencing that was written about in the second and third decades of the $16^{\text {th }}$ century.

\section{V.4. Dissimilarities}

Although similarities tend to be very obvious links between one source or system and another, the dissimilarities tend to be more important. Why did one master choose not to include a technique or concept in his system, when another master thought it was important? It is too easy to make assumptions that one system is like another because of some obvious cosmetic similarities, when in fact the core principles and the stylistic elements of the two systems are radically different. ${ }^{117}$

What are the dissimilarities between the longsword of the Kölner Fechtbuch and the longsword of the Liechtenauer tradition? It is important to examine these, so that we do not make false assumptions based only on cosmetic similarities.

In the Liechtenauer tradition, especially the $15^{\text {th }}$ century styles and systems, thrusting is a major component. Thrusts were very common as follow-up actions in the bind, but could also be used as Indes actions before the bind occurred, such as with Ansetzen for example. Cuts could become thrusts by way of Durchwechseln, and the action of Zucken (a disengagement above the opponent's blade) could sometimes result in either an Oberhaw or a thrust. Comparatively, the Kölner Fechtbuch involves only a single feinted thrust in the longsword treatise, and there are no instructions to "stab him in the face", as is such a common refrain in Ringeck and the anonymous gloss in the Codex 44.A.8.

There is also no mention of winding in the bind in the Kölner Fechtbuch. Its technique of der sprech vinster does use the phrase "make a wind", but it is not an offensive action, merely a motion to put yourself into a position in order to perform the actions of der sprech vinster. Therefore, winding is a critical stylistic element of the Liechtenauer tradition that is missing from the Kölner Fechtbuch.

Another two critical components of the Liechtenauer tradition are the Vier Leger and the Funff Hewen (also known as the Verbogne Hewe or the Meisterhawen). The Kölner Fechtbuch

117 Keith Farrell, 'The concept of "style" in HEMA', video clip of a presentation at the Dreynevent 2013, hosted on Youtube, 2013, <https://www.youtube.com/watch?v=4ktj1qUU26E > accessed 13th December 2014. 
does in fact describe its versions of the veyr leger and the ". $V$. hewe", but the leger are different, and the hewe do not have the same role, importance or emphasis as the Funff Hewen do in the Liechtenauer tradition. Although the Kölner Fechtbuch does contain these two concepts, with the same names as in the Liechtenauer tradition, the implementations are completely different and have a different function in the overall style of the system.

In a similar fashion, the Kölner Fechtbuch does have some techniques bearing the same names as techniques or guard positions in the Liechtenauer tradition, such as der ocks, der olber and der sprech vinster, but the names usually refer to a different implementation of a technique, or to a striking sequence rather than to a guard position. Even though some familiar terms can be found in the Kölner Fechtbuch, the implementation is usually very different.

On the whole, there are many cosmetic similarities, but the dissimilarities between the Kölner Fechtbuch and the Liechtenauer tradition are powerfully compelling. The author of the Kölner Fechtbuch may have come across fencing teachings similar to that in the Liechtenauer tradition, perhaps by way of the Marxbrïder, but it would be folly to treat the longsword treatise of the Kölner Fechtbuch as anything but a unique system.

\section{SIMILARITY TO OTHER TRADITIONS AND SOURCES}

The Liechtenauer tradition was not the only method of fighting with the longsword in the Holy Roman Empire during the $15^{\text {th }}$ and $16^{\text {th }}$ centuries. Although the vast majority of the extant Fechtbücher from this time period do have connections with the Liechtenauer tradition, there are some other sources outwith the tradition. It is worth comparing the Kölner Fechtbuch with these other outlying sources as well.

\section{VI.1. Codex Guelf 83.4 August.8 ${ }^{\circ}$}

The Codex Guelf 83.4 Angust. $8^{\circ}$ is a unique treatise outwith any known fighting tradition. It deals with the longsword, along with dussack, halberd, staff, dagger, and wrestling. The book is dated to 1591 , so it was compiled at the end of the $16^{\text {th }}$ century. In terms of time, it is probably too many decades removed from the Kölner Fechtbuch to have any sensible relationship.

However, there are a number of similarities. The Codex Guelf 83.4 August. $8^{\circ}$ is also outwith the Liechtenauer tradition, and it depicts feders in the hands of each of the longsword fencers. The longsword treatise deals mainly with cutting/striking and grappling techniques, without many thrusts and without winding actions in the bind. It discusses several disarms and throws, some of which are similar to those found in the 
Kölner Fechtbuch. Interestingly, a major stylistic element is changing the height of the attacks, often going from high-to-low, ${ }^{118}$ a concept not discussed in the Kölner Fechtbuch.

Like the Kölner Fechtbuch, the target areas are mainly the arms and the head, although there are also strikes to the torso and the legs. There are very few examples of strikes to the hands, although it does describe techniques to crush the fingers at close range for several of its disciplines. ${ }^{119}$ The illustrations tend to depict the arms outstretched towards the opponent when striking with an Oberhaw, with considerable leaning of the body in all movements. ${ }^{120}$

Even as a source outwith the Liechtenauer tradition, the Codex Guelf 83.4 August.8 uses a Zwerhaw-like action with regularity, ${ }^{121}$ more so than the Kölner Fechtbuch.

Although there are some similarities between the Kölner Fechtbuch and the Codex Guelf 83.4 August. $8^{\circ}$, we must conclude that they are showing two rather different styles of fighting, with a different strategy and method of achieving their objectives.

\section{VI.2. Die Blume des Kampfes}

There is a group of manuscripts from the Holy Roman Empire that has been given the name Die Blume des Kampfes by modern historical fencing scholars, for the resemblance they bear to the methods of Fiore de' Liberi, described in a book called "The Flower of Battle" (hence the German name for the group). ${ }^{122}$ These manuscripts range in date from the 1420 s to 1623 , so they cover both the $15^{\text {th }}$ and $16^{\text {th }}$ centuries, as well as the first quarter of the $17^{\text {th }}$ century. ${ }^{123}$

The manuscripts from Die Blume des Kampfes contain fighting systems outwith the Liechtenauer tradition and cover a large range of weapons and disciplines. Many of the illustrations display techniques and situations that are very similar to those found in the fighting system of Fiore de' Liberi, with significant emphasis on grappling, disarms and "Giocco Stretto" plays. Unfortunately there is no text to accompany the illustrations; Die Blume des Kampfes seems to contain a tradition of images rather than a tradition of text.

It does not contain many winding actions, but it does involve a lot of thrusting. There is also considerable use of halfswording, both with the point for thrusts and with the hilt

118 Anonymous, 1591. Wolfenbüttel, Herzog-August Bibliothek, Codex Guelf 83.4 August $8^{\circ}$, fols. 6v, 7r, 22v, 31r, 37r, 41v, 82r, 82v.

119 Ibid., fols. $10 \mathrm{v}, 24 \mathrm{v}, 45 \mathrm{v}$.

120 Ibid., fols. $2 \mathrm{r}-19 \mathrm{v}$.

${ }^{121}$ Ibid., fols. 2v, 4v, 6v, 7v, 18v.

122 "Die Blume des Kampfes." Wiktenauer,

<http://wiktenauer.com/wiki/Die_Blume_des_Kampfes>, accessed 13 ${ }^{\text {th }}$ December 2014.

123 Ibid. 
furniture for striking and for grappling/throwing purposes. This is a major difference between Die Blume des Kampfes and the Kölner Fechtbuch.

Furthermore, in Die Blume des Kampfes, the illustrations of strikes show the fencers with their hands low and the arms not entirely outstretched, as per many $15^{\text {th }}$ century illustrations of fencing systems from several different manuscripts. Comparatively, the Kölner Fecbtbuch calls for outstretched arms explicitly:

alle bewe durch das gesicht mit gestreckten armen ${ }^{124}$

all cuts through the face with outstretched arms. ${ }^{125}$

This difference in hand height and extension/retraction of the arms creates a major difference in the striking mechanics required to reach the illustrated/described positions.

Again we must conclude that the Kölner Fechtbuch is a totally different method of fighting from the system illustrated in the manuscripts of Die Blume des Kampfes.

\section{RELEVANCE TO THE FECHTSCHULE}

The Fechtschule, or "fighting school", was an event held from the late $15^{\text {th }}$ century until the $17^{\text {th }}$ century, ${ }^{126}$ and in some places the tradition of the Fechtschule continued into the $18^{\text {th }}$ century. $.^{127},{ }^{128}$ It often consisted of a procession or parade, fencing competitions with various weapons, sometimes lessons or practice time, ${ }^{129}$ and sometimes elements of the flag waving tradition. ${ }^{130}$ Kevin Maurer has suggested that "the very use of the word Fechtschulen" might be linked with "the initial formation of the Marxbrïder."131 However, sometimes the word "Fechtschule" would refer simply to a fencing master's

124 MS Best.7020 (W*)150, fol. 2v. Transcribed by Matthias Johannes Bauer, 2009.

125 Ibid. Translated by Keith Farrell, 2014.

126 Kevin Maurer, 'Further Insights into the Fechtschulen', 2013, <https://docs.google.com/file/d/0B4Wy4VUTvpKKZGZPclg4ZDdkbEU>, accessed 17th December 2014, p. 2.

127 Jens P. Kleinau, 'Chronicle of Fencing Guilds in Breslau, Wrocław', Hans Talhoffer as seen by Jens P. Kleinau, 2011, <http://talhoffer.wordpress.com/2011/06/16/chronicle-of-fencing-guilds-inbreslau-wroclaw/>, accessed 17th December 2014.

128 Jens P. Kleinau, 'Chronicle of the Fencing Guilds in Augsburg', Hans Talhoffer as seen by Jens P. Kleinau, 2012, <http://talhoffer.wordpress.com/2012/04/25/chronicle-of-the-fencing-guilds-inaugsburg/>, accessed 17th December 2014.

129 Tlusty, The Martial Ethic, pp. 210-217.

130 Maurer, 'Further Insights into the Fechtschulen', pp. 3-4.

131 Ibid., p. 2. 
school where he would teach students on a weekly basis; ${ }^{132}$ for the purpose of this article, the Fechtschule for comparison will be the public spectacle with competitions and merrymaking, and comparison will also be extended to the similar competitions in France and Belgium in the same period. ${ }^{133}$

The Fechtschule gave citizens an opportunity to test and improve their fencing skills, and it gave the city an opportunity to hold a festival and raise revenue from the sideshows and entertainment in a similar fashion to the festivities surrounding shooting matches. ${ }^{134}$ The city could justify its expenditure on behalf of a Fechtschule with the rationale that such activities "instilled men with all of the virtues of the martial ethic, including courage, strength, and respect for fair play."135

The fencing master governed the competitions carefully, and there were strict rules regarding conduct of fencers, and techniques that were forbidden for safety reasons. ${ }^{136}$ The fencing master would be equipped with a long wooden staff, with which he could separate combatants to help ensure their safety. ${ }^{137}$ He could make profit from holding such an event by collecting fees from participants and spectators, ${ }^{138}$ or even by petitioning the city council for financial help, ${ }^{139}$ although it was rarely lucrative; ${ }^{140}$ the fencing master therefore had incentive (as well as legal obligations) to ensure that his pool of potential participants remained alive and able to participate as often as possible. It appears that the issue of safety was taken seriously.

There were usually rules regarding forbidden techniques as well as those governing conduct and manners. Lists of forbidden techniques included such items as thrusts, pommel strikes, wrestling, breaking the arm, gouging the eyes, dirty tricks (or unmanly

132 Jürg Gassmann, 'Fechtordnung of the City of Solothurn', HROARR, 2014, <http://www.hroarr.com/fechtordnung-of-the-city-of-solothurn/>, $\quad$ accessed $\quad 17^{\text {th }}$ December 2014.

133 The rationale for extending the comparison is that the French and Belgian fencing competitions seem complementary to the German Fechtschulen in nature and intent, with similar rules and aspirations, although slightly different implementations in the format of the competition and the event itself.

134 Tlusty, The Martial Ethic, p. 214.

135 Ibid.

136 'What exactly were the Fechtschulen?', Kampf Kunst, 2010, <http://kunstfechter.blogspot.co.uk/2010/01/what-exactly-were-fechtschulen.html>, accessed $17^{\text {th }}$ December 2014.

137 Maurer, 'Further Insights into the Fechtschulen', pp. 6-7.

138 Tlusty. The Martial Ethic, p. 211.

139 Ibid., p. 214.

140 Ibid., p. 215. 
techniques), or hitting above or below the fencing master's staff. ${ }^{141,142,143}$ Some rule sets demanded that combatants strike only with the flat of the blade, with punishments for those who struck with the edge, ${ }^{144}$ and some also forbade striking at the hands (or other body parts, limiting the valid target areas for scoring). ${ }^{145,146}$ Some rules prohibited bodyto-body contact, forbidding grappling entirely. ${ }^{147}$

Although safety was clearly a priority, many bouts were nonetheless decided by scoring the highest bleeding wound, or causing the opponent to bleed from the head. ${ }^{148,149}$

It is from such lists that we can see easy comparisons between the longsword treatise of the Kölner Fechtbuch and the context of the Fechtschulen. In the Kölner Fechtbuch, there are no thrusts that are intended to land on the opponent, merely a single feinted thrust in der ocks. The cuts in the Kölner Fechtbuch can be performed with the long edge or the short edge, or with the flat in some cases, showing a certain versatility and adaptability that would be valuable for citizens who might be expected to use their swords in a range of conditions from war to city guard duty to sport. There are no explicit instructions in the Kölner Fechtbuch to target the hands or the legs, but many exhortations and instructions to reach out and cut to the head, as if trying to give the highest bleeding wound. There are no pommel strikes, nor are there any instructions to break the arms or gouge the eyes in the techniques that deal with wrestling at the sword.

However, there are some techniques in the Kölner Fechtbuch that would break the rules of safety in the Fechtschule or other related fencing competitions from the $15^{\text {th }}$ and $16^{\text {th }}$ centuries. For example, some Franco-Belgian tournaments forbade grappling entirely, ${ }^{150}$

141 Daniel Jaquet, 'Fighting in the Fightschools late XVth, early XVIth century', Acta Periodica Duellatorum, 1 (2013), 47-66, here p. 59.

142 'What exactly were the Fechtschulen?'.

143 Maurer, 'Further Insights into the Fechtschulen', pp. 6-8.

144 Matt Galas, 'Guidelines for Franco-Belgian Tournaments', Schola Forum, 2012, <http://www.fioredeiliberi.org/phpBB3/viewtopic.php?f=3\&t=18693>, $\quad$ accessed $17^{\text {th }}$ December 2014.

145 Olivier Dupuis, 'Organization and Regulation of Fencing in the Realm of France in the Renaissance', Acta Periodica Duellatorum, 2 (2014), 233-254, here p. 242.

146 Matt Galas, 'Historical Rule-Sets', Schola Forum, 2010, $<$ http://www.fioredeiliberi.org/phpBB3/viewtopic.php?f=3\&t=16311>, $\quad$ accessed $17^{\text {th }}$ December 2014.

147 Galas, 'Guidelines for Franco-Belgian Tournaments'.

148 Jaquet, 'Fighting in the Fightschools', p. 59.

149 Olivier Dupuis, 'A fifteenth-century fencing tournament in Strasburg', Acta Periodica Duellatorum, 1 (2013), 67-79, here pp. 74-75.

150 Galas, 'Guidelines for Franco-Belgian Tournaments'. 
while the Kölner Fechtbuch includes throws and disarms in the longsword treatise. ${ }^{151}$ The technique called den gassen hewe (part of the yser porte sequence) is not described in the longsword treatise, but the messer treatise describes it as an Oberhaw from the right followed by an Underhaw from the left, presumably going back up along the same path. ${ }^{152}$ From experience in sparring, this sort of action can be very dangerous for an opponent's hands and arms if he tries to interrupt your flow with a technique such as Nacbraissen. Hitting at the hands is forbidden in some Fechtschule rules, and therefore den gassen hewe may be an example of an inappropriate technique if it strikes at an invalid target area.

Although these examples do show some techniques that may not have been permissible under some Fechtschule rules, it is important to realise that different Fechtschulen operated under different rules, and that there was no one overarching rule set governing all Fechtschulen in the country as is the case with modern sports. Upon requesting permission from the city council to hold a Fechtschule, the fencing master had to submit the rules and ordinances for his event; ${ }^{153}$ there was no single complete and universally accepted rule set that Fechtschulen were expected to follow by default. It is entirely possible that while techniques from the Kölner Fechtbuch, such as wrestling at the sword, might have been banned under some rule sets, they may have been permissible at other Fechtschulen elsewhere. The Kölner Fechtbuch appears to follow the rules that seem common across virtually all of these contests, such as the ban against thrusting.

Many of these common rules seem to mirror the laws regarding self-defence with a weapon. Thrusting with a knife or with a sword was considered a much worse offence than cutting a man, and striking with the flat of the blade was one way to show that you were not trying to escalate the fight while still defending yourself or preserving your honour. ${ }^{154}$

It is therefore reasonable to conclude that the longsword treatise in the Kölner Fecbtbuch illustrates a method of fighting for civilians and citizens that was suitable for application in the Fechtschulen, and for other non-war challenges and altercations with weapons in daily life.

\footnotetext{
${ }^{151}$ MS Best.7020 (W*)150, fols. 6v-7v.

152 Ibid., fol. $14 \mathrm{v}$.

153 'What exactly were the Fechtschulen?'.

154 Tlusty, The Martial Ethic, p. 100.
} 


\section{CONCLUSIONS}

The Kölner Fechtbuch is a unique source of information about a style of fighting not described or illustrated in any other source from the $15^{\text {th }}$ or $16^{\text {th }}$ century, from within or without the Liechtenauer tradition. The style bears some resemblance to that of the Liechtenauer tradition, but by looking at the dissimilarities as well as the similarities, it is clear that the differences are overpowering and that the style described is not a continuation of the Liechtenauer tradition.

The longsword material bears more resemblance to other $16^{\text {th }}$ century longsword styles than to the $15^{\text {th }}$ century styles, and there is remarkable overlap in stylistic elements and guiding principles between the conduct of the fight in the style of the Kölner Fechtbuch and in the style of the Fechtschulen.

It would therefore be a mistake for practitioners working with the Kölner Fechtbuch to attempt to reconstruct its longsword system without first understanding the rules and conduct of the Fechtschulen. Familiarity with other $16^{\text {th }}$ century fencing treatises would be helpful, particularly with that of Joachim Meyer. Furthermore, an understanding of the $16^{\text {th }}$ century traditions of craft guilds, armed guilds, and the martial ethic of the indigenous populace can only help a reconstruction attempt; it would be folly to attempt an interpretation of the Kölner Fechtbuch without such contextual studies to inform it and to provide rationale for some of the techniques and ways to approach the fight.

One final consideration is that while the longsword fencing system from the Kölner Fechtbuch is a good example of $16^{\text {th }}$ century "sport fencing" or "schulfechten", this is not a case of playing a game for points, wrapped in protective clothing, as in modern fencing or even modern competitive HEMA. The schulfechten of the $16^{\text {th }}$ century was a violent and technical affair, often requiring blood to be drawn from the head in order to win, and requiring vast amounts of control and skill with the sword not only to keep one's self safe from harm, but to strike the opponent legally in such a way as to draw blood from a valid target area but without maiming or disabling him. From this point of view, "sport fencing" should not be a derogatory term for $16^{\text {th }}$ century fencing arts, but should be viewed as the application of tremendous fencing skill within a certain civilian context. 


\section{BIBLIOGRAPHY}

\section{IX.1. Original Treatises}

Anonymous, Hs.3227a, c.1389. Hosted by the Wiktenauer, accessed 17th December 2014. $<$ http://wiktenauer.com/wiki/Codex_Döbringer_(MS_3227a)>

Edited by Dierk Hagedorn (Herne: VS-Book, 2008).

Translated by Keith Farrell, 2014.

Anonymous, MS KK 5013, c.1430s. Hosted by the Wiktenauer, accessed $17^{\text {th }}$

December 2014. <http://wiktenauer.com/wiki/Gladiatoria_(MS_KK5013)>

Anonymous, Codex 44.A.8, 1452. Hosted by the Wiktenauer, accessed $17^{\text {th }}$

December 2014.

<http://wiktenauer.com/wiki/Codex_Danzig_(Cod.44.A.8)>

Anonymous, MS Best.7020 (W*) 150, c.1500s. Hosted by the Wiktenauer, accessed $17^{\text {th }}$

December 2014.

<http://wiktenauer.com/wiki/Fechtregeln_(MS_Best.7020_(W*)150)>

Transcribed by Dieter Bachmann, 2010.

Translated by Keith Farrell, 2014.

Anonymous, Codex Guelf 83.4 August. $8^{\circ}, 1591$. Hosted by the Wiktenauer, accessed $17^{\text {th }}$

December 2014.

$<$ http://wiktenauer.com/wiki/Das_Ander_Theil_Des_Newen_Kůnstreichen_Fecht bůches_(Cod.Guelf.83.4_Aug. $\left.8^{0}\right)>$

Translated by David Kite, 2013.

Anonymous, Codex 10799,1623 . Hosted by the Wiktenauer, accessed $17^{\text {th }}$

December 2014,

<http://wiktenauer.com/wiki/Büech_von_fechter_Vnnd_Ringstückhen_zũ_Ross_vnn d_Fuoß_(Cod.10799) >

"Die Blume des Kampfes". Hosted by the Wiktenauer, accessed 17th December 2014.

$<$ http://wiktenauer.com/wiki/Die_Blume_des_Kampfes>

Hanko Döbringer, Andres Juden, Josts von der Nyssen, and Niclas Prewßen, Hs.3227a, c.1389. Hosted by the Wiktenauer, accessed 17th December 2014. $<$ http://wiktenauer.com/wiki/Codex_Döbringer_(MS_3227a)>

Ludvig VI von Eyb, MS B.26, c.1500. Hosted by the Wiktenauer, accessed $17^{\text {th }}$ December 2014, <http://wiktenauer.com/wiki/Eyb_Kriegsbuch_(MS_B.26)>

Peter Falkner, MS KK 5012, c.1495. Hosted by the Wiktenauer, accessed $17^{\text {th }}$ December 2014.

<http://wiktenauer.com/wiki/Kunste_Zu_Ritterlicher_Were_(MS_KK5012)> 
Paulus Hector Mair, MS Dresd.C.93, c.1542. Hosted by the Wiktenauer, accessed 17th December 2014.

$<$ http://wiktenauer.com/wiki/Opus_Amplissimum_de_Arte_Athletica_(MSS_Dres d.C.93/C.94)>

Translated by Keith P. Myers, 2011.

Paulus Hector Mair. Codex icon.393, 1550. Digitally reproduced by the Bayerische

StaatsBibliothek, accessed $17^{\text {th }}$ December 2014. <http://daten.digitale-

sammlungen.de/0000/bsb00006570/images/index.html>

Hans Medel, Codex I.6.2 .5, 1539. Digitally reproduced by the Universitätsbibliothek Augsburg, accessed 17 th December 2014. <http://media.bibliothek.uniaugsburg.de $/$ node?id $=47755>$

Joachim Meyer, $M S A .4^{\circ} .2,1560$. Hosted by the Wiktenauer, accessed $17^{\text {th }}$ December 2014.

<http://wiktenauer.com/wiki/Joachim_Meyers_Fäktbok_(MS_A.4'.2)>

Translated by Kevin Maurer, 2012. Accessed 17th December 2014.

<https://sites.google.com/site/jochimmeyer1560/>

Joachim Meyer, Gründtliche Beschreibung der Kunst des Fechtens, 1570. Hosted by the Wiktenauer, accessed 17th December 2014.

$<$ http://wiktenauer.com/wiki/Gründtliche_Beschreibung_der_Kunst_des_Fechten s_(Joachim_Meÿer)>

Andre Paurñfeyndt, Ergrundung Ritterlicher Kunst der Fechterey, E.1939.65.357, 1516.

Hosted by the Wiktenauer, accessed 17th December 2014.

$<$ http://wiktenauer.com/wiki/Ergrundung_Ritterlicher_Kunst_der_Fechterey_(An dre_Paurñfeyndt) $>$

Sigmund Ringeck, MS E.1939.65.341, 1508. Hosted by the Wiktenauer, accessed $17^{\text {th }}$ December 2014.

<http://wiktenauer.com/wiki/Glasgow_Fechtbuch_(MS_E.1939.65.341)> Translated by Keith Farrell, 2014.

Sigmund Ringeck, MS Dresden C487, c.1510. Hosted by the Wiktenauer, accessed $17^{\text {th }}$ December 2014.

<http://wiktenauer.com/wiki/Codex_Ringeck_(MS_Dresd.C.487)>

Translated by Keith Farrell, 2014.

Jakob Sutor, New Kinstliches Fecbtbuch, 1612. Hosted by the Wiktenauer, accessed $17^{\text {th }}$ December 2014.

<http://wiktenauer.com/wiki/New_Kůnstliches_Fechtbuch_(Jakob_Sutor_von_Ba den) $>$

Translated by Keith P. Myers, 2010.

Hans Talhoffer, Codex icon.394a, 1467. Hosted by the Wiktenauer, accessed $17^{\text {th }}$

December 2014.

$<$ http://wiktenauer.com/wiki/Talhoffer_Fechtbuch_(Cod.icon._394a)> 


\section{IX.2. Documents containing Transcriptions, Translations}

1 'Handschriften (W*) (Best. 7020) 150. Fechtregeln.', Das digitale Historische Archiv Köln, $<$ http://historischesarchivkoeln.de/de/lesesaal/verzeichnungseinheit/173032/Best. $+7020+150+$ Fechtregeln $>$, accessed 9th December 2014.

Bachmann, Dieter, 'Cologne Fechtbuch (English translation)' Schwertfechten.ch, 2014, $<$ http://schwertfechten.ch/pdf/cologne_fechtbuch_english.pdf $>$, accessed $9^{\text {th }}$ December 2014.

Jaquet, Daniel'Travaux de transcription/traduction de documents sources Kölner Fechtbuch', Association GAGS (Gebennensis Artium Gladiatorium Schola), 2010, <http://gagschola.bluemindmusic.com/files/recherche/dj.trad.hsbest7020.pdf>, accessed $9^{\text {th }}$ December 2014.

Meier, Andreas and Wiedner, Marita, 'Transkription von HS Best.7020 (alt W*Nr.150)', Gesellschaft für pragmatische Schriftlichkeit, 2007, <http://www.pragmatischeschriftlichkeit.de/Best7020.html>, accessed $9^{\text {th }}$ December 2014.

Wallhausen, James, 'The Fight-Lore of the Long Sword from the Kölner Fechtbuch (MS Best.7020)', Paleoeskirmology Historical Combat Systems, 2012.

\section{IX.3. Books, Journals}

Acutt, James, 'The Liechtenauer Zedel as Rhyme', unpublished, work in progress, 2012.

Anglo, Sydney, The Martial Arts of Renaissance Europe (New Haven: Yale University Press, 2000).

Bauer, Matthias Johannes, Langes Schwert und Schweinespieß. Die anonyme Fechthandschrift aus den verscbütteten Beständen des Historischen Archivs der Stadt Köln (Graz: ADEVA, 2009).

Dupuis, Olivier, 'A fifteenth-century fencing tournament in Strasburg', Acta Periodica Duellatorum, 1 (2013), 67-79.

Dupuis, Olivier, 'Organization and Regulation of Fencing in the Realm of France in the Renaissance', Acta Periodica Duellatorum, 2 (2014), 233-254.

Farrell, Keith and Alex Bourdas, AHA German Longsword Study Guide (Glasgow: Fallen Rook Publishing, 2013).

Farrell, Keith, 'The Pedagogical Skill of Andre Lignitzer, a 15th Century Fencing Master', Katsujinken: A Sword Arts Journal, 5(2013), pp. 12-15.

Farrell, Keith, 'Research into Historical European Martial Arts', Encased in Steel Anthology I., ed. by Keith Farrell (Glasgow: Fallen Rook Publishing, 2015), pp. 65-85.

Farrell, Keith, 'Validating What We Do in Martial Arts', in Encased in Steel Anthology I, ed. by Keith Farrell (Glasgow: Fallen Rook Publishing, 2015), pp. 199-208.

Forgeng, Jeffrey, The Art of Combat: A German Martial Arts Treatise of 1570 (New York: Palgrave MacMillan, 2006). 
Gattermann, Günter, Handschriftencensus Rheinland. Erfassung mittelalterlicher Handschriften im rheinischen Landesteil von Nordrbein-Westfalen mit einem Inventar (Düsseldorf: Wiesbaden, 1993).

Jaquet, Daniel, 'Fighting in the Fightschools late XVth, early XVIth century', Acta Periodica Duellatorum, 1 (2013), 47-66.

Menne, Karl, Deutsche und niederländische Handschriften. Mitteilungen aus dem Stadtarchiv von Köln: Die Handschriften des Archivs, No. 10, Dept. 1, Part 2 (Köln: Verlan von Paul Neubner, 1937).

Tlusty, Ann B., The Martial Ethic in Early Modern Germany: Civic Duty and the Right of Arms (Basingstoke: Palgrave Macmillan, 2011).

Walczak, Bartłomiej, 'Bringing Lost Teachings Back to Life - a Proposed Method for Interpretation of Medieval and Renaissance Fencing Manuals', IDO MOVEMENT FOR CULTURE. Journal of Martial Arts Anthropology, 11/2 (2011), 47-54.

\section{IX.4. Online Resources}

'What exactly were the Fechtschulen?', Kampf Kunst, 2010, <http://kunstfechter.blogspot.co.uk/2010/01/what-exactly-werefechtschulen.html>, accessed $17^{\text {th }}$ December 2014

Farrell, Keith, 'Comparing how swords were used - the importance of the hilt', Encased in Steel, 2012, <www.encasedinsteel.co.uk/2012/12/28/comparing-how-swordswere-used-the-importance-of-the-hilt/>, accessed 11 th December 2014.

Farrell, Keith, 'Why do certain techniques have a name, when others do not?', Encased in Steel, 2013, <www.encasedinsteel.co.uk/2013/05/17/why-do-certain-longswordtechniques-have-a-name-when-others-do-not/>, accessed 13 ${ }^{\text {th }}$ December 2014.

Galas, Matt Matt Galas, 'Historical Rule-Sets', Schola Forum, 2010, $<$ http://www.fioredeiliberi.org/phpBB3/viewtopic.php?f=3\&t=16311>, accessed 17th December 2014.

Galas, Matt, 'Guidelines for Franco-Belgian Tournaments', Schola Forum, 2012, $<$ http://www.fioredeiliberi.org/phpBB3/viewtopic.php?f=3\&t=18693>, accessed 17th December 2014.

Gassmann, Jürg, 'Fechtordnung of the City of Solothurn', HROARR, 2014, $<$ http://www.hroarr.com/fechtordnung-of-the-city-of-solothurn/ $>$, accessed $17^{\text {th }}$ December 2014.

Kleinau, Jens P., 'Chronicle of Fencing Guilds in Breslau, Wrocław', Hans Talboffer as seen by Jens P. Kleinau, 2011, <http://talhoffer.wordpress.com/2011/06/16/chronicle-of-fencing-guilds-inbreslau-wroclaw/>, accessed $17^{\text {th }}$ December 2014.

Kleinau, Jens P. , 'Chronicle of the Fencing Guilds in Augsburg', Hans Talhoffer as seen by Jens P. Kleinau, 2012, <http://talhoffer.wordpress.com/2012/04/25/chronicle-ofthe-fencing-guilds-in-augsburg/>, accessed 17th December 2014. 
Maurer, Kevin'Further Insights into the Fechtschulen', 2013, <https://docs.google.com/file/d/0B4Wy4VUTvpKKZGZPclg4ZDdkbEU>, accessed $17^{\text {th }}$ December 2014.

Norling, Roger, 'The WhatChaMaCallit-Schwert', HROARR, 2013, $<$ http://www.hroarr.com/the-feder-whatchamacallit/ $>$, accessed $11^{\text {th }}$ December 2014.

Norling, Roger, 'Fechtschwert or a blunt longsword?', HROARR, 2011, <http://www.hroarr.com/federschwert-or-a-blunt-longsword/>, accessed $11^{\text {th }}$ December 2014.

\section{IX.5. Miscellaneous Articles and Documents}

'Köln, Hist. Archiv der Stadt, Best. 7020 (W*) 150', Handschriftencensus, <http://www.handschriftencensus.de/13145>, accessed 9th December 2014.

'Construction worker confesses in Cologne archive collapse case.', The Local: Germany's News in English, 2010, <http://www.thelocal.de/20100209/25131>, accessed 9th December 2014.

'Historisches Archiv der Stadt Köln: Liste der im Original nutzbaren Archivalien (Stand November 2014).', Das digitale Historiche Archiv Köln, November 2014, <http://www.archive.nrw.de/kommunalarchive/kommunalarchive_i1/k/Koeln/BilderKartenLogosDateien/20141117_im_Original_nutzbar.pdf >, accessed 9th December 2014. 